\title{
c-Src Is Required for Glial Cell Line-Derived Neurotrophic Factor (GDNF) Family Ligand-Mediated Neuronal Survival via a Phosphatidylinositol-3 Kinase (PI-3K)-Dependent Pathway
}

\author{
Mario Encinas, ${ }^{1,2}$ Malú G. Tansey, ${ }^{2}$ Brian A. Tsui-Pierchala, ${ }^{2}$ Joan X. Comella, ${ }^{1}$ Jeffrey Milbrandt, ${ }^{3}$ and \\ Eugene M. Johnson Jr² \\ ${ }^{1}$ Grup de Neurobiologia Molecular, Departament de Ciències Mèdiques Basiques, Facultat de Medicina, Universitat de \\ Lleida, 25198 Lleida, Spain, and 2Departments of Neurology and Molecular Biology and Pharmacology, and ${ }^{3}$ Department \\ of Pathology and Internal Medicine, Washington University School of Medicine, St. Louis, Missouri 63110
}

The glial cell line-derived neurotrophic factor (GDNF) family ligands (GFLs), consisting of GDNF, neurturin, persephin, and artemin, signal via a multicomponent complex composed of Ret tyrosine kinase and the glycosyl-phosphatidylinositol (GPI)anchored coreceptors GFR $\alpha 1-\alpha 4$. In previous work we have demonstrated that the localization of Ret to membrane microdomains known as lipid rafts is essential for GDNF-induced downstream signaling, differentiation, and neuronal survival. Moreover, we have found that Ret interacts with members of the Src family kinases (SFK) only when it is localized to these microdomains. In the present work we show by pharmacological and genetic approaches that Src activity was necessary to elicit optimal GDNF-mediated signaling, neurite outgrowth, and survival. In particular, p60Src, but not the other ubiquitous SFKs, Fyn and Yes, was responsible for the observed effects.
Moreover, Src appeared to promote neuronal survival via a phosphatidylinositol-3 kinase (PI-3K)-dependent pathway because the PI-3K inhibitor LY294002 prevented GFL-mediated neuronal survival and prevented activated Src-mediated neuronal survival. In contrast, the inhibition of Src activity had no effects on NGF-mediated survival, indicating that the requirement for Src was selective for GFL-mediated neuronal survival. These data confirm the importance of protein-protein interactions between Ret and raft-associated proteins in the signaling pathways elicited by GDNF, and the data implicate Src as one of the major signaling molecules involved in GDNF-mediated bioactivity.

Key words: Ret; GDNF family ligands (GFLs); Src family kinases (SFKs); lipid rafts; phosphatidylinositol-3 kinase (PI-3K); cerebellar granule neurons
The glial cell line-derived neurotrophic factor (GDNF) family ligands (GFLs) constitute a group of structurally related neurotrophic factors: GDNF (Lin et al., 1993), neurturin (NRTN; Kotzbauer et al., 1996), persephin (PSPN; Milbrandt et al., 1998), and artemin (ARTN; Baloh et al., 1998). The GFLs can support neuronal populations in the CNS and, except for PSPN, a variety of peripheral neuronal populations (Lin et al., 1993; Henderson et al., 1994; Buj-Bello et al., 1995; Ebendal et al., 1995; Oppenheim et al., 1995; Trupp et al., 1995; Kotzbauer et al., 1996; Baloh et al., 1998; Cacalano et al., 1998; Heuckeroth et al., 1998; Horger et al., 1998; Milbrandt et al., 1998). Analysis of mice deficient for some of the GFLs as well as their receptors (see below) has identified neuronal populations that require GFLs during neural development (for review, see Airaksinen et al., 1999; Baloh et al., 2000).

GFLs signal via a multicomponent receptor system consisting of the transmembrane receptor tyrosine kinase (Ret), which does

Received Sept. 13, 2000; revised Nov. 16, 2000; accepted Dec. 11, 2000.

This work was supported by National Institutes of Health Grants AG-13729 (E.M.J.) and AG-13730 (J.M.) and by the Commission for Cultural, Educational, and Scientific Exchange between the United States of America and Spain. M.E. is a predoctoral fellow of the Generalitat de Catalunya. We thank our colleagues from the Johnson, Milbrandt, and Comella laboratories for many discussions and a critical reading of this manuscript. In addition, we thank Krista Moulder and Charles Harris for their assistance in the dissection and primary culture of cerebellar granule cells and Montse Iglesias and Robert H. Baloh for many helpful discussions.

M.E. and M.G.T. contributed equally to this work.

Correspondence should be addressed to Dr. Eugene M. Johnson, Jr. or Dr. Jeffrey Milbrandt, Washington University School of Medicine, 4566 Scott Avenue, Box 8103, St. Louis, MO 62110. E-mail: ejohnson@pcg.wustl.edu or jeff@pathbox.wustl.edu. Copyright (C) 2001 Society for Neuroscience $0270-6474 / 01 / 211464-09 \$ 15.00 / 0$ not bind GFLs directly, and a high-affinity ligand-binding glycosyl-phosphatidylinositol (GPI)-linked coreceptor (GFR $\alpha$ ). Four coreceptors have been characterized (GFR $\alpha 1-\alpha 4)$ that interact with preferred GFLs to provide ligand specificity, although some degree of promiscuity exists. GDNF interacts mainly with GFR $\alpha 1$, whereas NRTN interacts with GFR $\alpha 2$, ARTN with GFR $\alpha 3$ (Airaksinen et al., 1999; Baloh et al., 2000), and PSPN with GFR $\alpha 4$ (Enokido et al., 1998; Lindahl et al., 2000).

One notable feature of GFR $\alpha$ s is their targeting to the outer leaflet of the plasma membrane via a GPI anchor (Jing et al., 1996; Treanor et al., 1996). This property predicts that these coreceptors will partition to detergent-insoluble, sphingolipidrich, and cholesterol-rich membrane microdomains that exist as rafts in the plasma membrane (Simons and Ikonen, 1997; Brown and London, 1998, 2000). The enrichment of these microdomains in signaling proteins such as Src family kinases (SFKs) has led to the hypothesis that these rafts may function as specialized signaling organelles (Anderson, 1998).

We have shown recently that, to achieve efficient downstream signaling and maximal levels of GDNF-mediated bioactivity, Ret must be recruited to lipid rafts by GFR $\alpha 1$. Moreover, activated Ret interacts with SFKs only when Ret is recruited to lipid rafts, although the Src-SH2 docking site on Ret is generated after GDNF stimulation irrespective of the localization of the receptor (Tansey et al., 2000). Thus, these data suggest that SFK may represent proximal signaling elements specifically compartmentalized into lipid rafts that are necessary for maximal downstream signaling of the optimal biological effects of GFLs. 
In the present work we investigated the relevance of the RetSFK association in GDNF-induced downstream signaling. We found that Src activity was necessary for optimal GDNFmediated Akt and mitogen-activated protein kinase (MAPK) phosphorylation and for neuronal survival and neurite outgrowth. Specifically, p60Src, but not the other ubiquitous SFKs Fyn and Yes, appeared to be the major target for activated Ret. PI-3K activity was necessary for GFL- and activated Srcmediated, but not NGF-mediated, neuronal survival. These data suggest that p60Src was a key proximal element in the signaling cascades initiated by GFLs.

\section{MATERIALS AND METHODS}

Neuroblastoma differentiation. Neuro2a neuroblastoma cells, which express Ret, but not GFR $\alpha$ s, were plated at 70,000 cells/well in a 12-well plate. Cells were transfected $24 \mathrm{hr}$ after plating by using Superfect transfection reagent (Qiagen, Valencia, CA) with an enhanced green fluorescent protein (EGFP) expression plasmid (Clontech, Palo Alto, CA) and either GPI-GFR $\alpha 1$ or transmembrane (TM)-GFR $\alpha 1$ expression plasmids (Tansey et al., 2000). When indicated, the cells were transfected with either a dominant-negative mutant of Src (catalog number 21-154; Upstate Biotechnology, Lake Placid, NY) or the corresponding empty vector (Upstate Biotechnology). After 12-16 hr of incubation with the DNA $(1.5 \mu \mathrm{g}$ total) the cells were rinsed with standard growth medium (MEM with Earle's salts, 10\% fetal bovine serum, nonessential amino acids, $100 \mathrm{U} / \mathrm{ml}$ penicillin, and $100 \mu \mathrm{g} / \mathrm{ml}$ streptomycin) and were incubated for an additional $24 \mathrm{hr}$ in growth medium. Then the cells were switched to $1 \%$ FBS-containing medium supplemented with the indicated amounts of GDNF with 4-amino-5(4-chlorophenyl)-7-( $t$-butyl)pyrazolo[3,4-d]pyrimidine (PP2, $1 \mu \mathrm{M})$ or 4-amino-7-phenylpyrazol[3,4-d]pyrimidine (PP3, $1 \mu \mathrm{M}$; CalbiochemNovabiochem, San Diego, CA). After 4-5 d, differentiation was scored by counting cells with neurites longer than two cell bodies present in 20 random fields in duplicate cultures. Counting was conducted by a naïve observer. The data shown are representative of three independent experiments.

Cerebellar granule cell survival. Rat cerebellar granule cell dissection and cultures were performed at postnatal day 7 (P7), as originally described by D'Mello et al. (1993) and as modified by Miller and Johnson (1996). Granule cell transfection of EGFP with the indicated constructs was performed by using a calcium phosphate protocol (Xia et al., 1996) modified by Moulder et al. (1999). To quantitate transfection results, we counted the number of initial EGFP-positive cells in designated fields (minimum of 150 cells) of two to four wells in a four-well dish (Nunc, Naperville, IL) per condition at $24 \mathrm{hr}$ after transfection. Cultures were rinsed twice in DMEM and switched to high potassium plus serum $(\mathrm{K} 25+\mathrm{S})$ medium, low potassium without serum medium $(\mathrm{K} 5-\mathrm{S})$, or $\mathrm{K} 5-\mathrm{S}$ supplemented with the indicated factors for $48 \mathrm{hr}$. After this period the number of EGFP-positive cells remaining in the same fields was scored in a blinded manner to obtain the percentage of neuronal survival. As for neuronal differentiation, PP2 and PP3 were used at $1 \mu \mathrm{M}$. Solvent concentrations (DMSO) never exceeded $0.1 \%$.

Immunoprecipitation. Neuro2a cells transfected with GPI-GFR $\alpha 1$ or TM-GFR $\alpha 1$ were stimulated, as were sympathetic neurons, with 30-50 $\mathrm{ng} / \mathrm{ml}$ GDNF for $10 \mathrm{~min}$. Cells were lysed on ice in cold coimmunoprecipitation buffer [containing (in mM) 50 Tris- $\mathrm{HCl}, \mathrm{pH} 7.5,1 \%$ Brij 96 or 1\% NP-40, $150 \mathrm{NaCl}, 1$ EDTA, 1 EGTA, $10 \mathrm{NaF}, 2$ Pafabloc, and 1 $\mathrm{Na}_{2} \mathrm{VO}_{4}$ plus $1 \mu \mathrm{g} / \mathrm{ml}$ leupeptin and $1 \mu \mathrm{g} / \mathrm{ml}$ aprotinin]. Cleared lysates were immunoprecipitated with $10 \mu \mathrm{l}$ of a goat anti-Ret antibody (C-19G for CGCs and Neuro2a cells or C-20 for SCGs; Santa Cruz, Santa Cruz, CA) and a mix of Protein A/Protein G agarose conjugates (Life Technologies, Gaithersburg, MD). Immunoblot analyses of Ret immune complexes with a second Ret antibody (C-19G for CGGs and Neuro2a cells or C-20 for SCGs; Santa Cruz) confirmed quantitative immunoprecipitation of Ret. Ret-associated Src family kinase immunoreactivity was detected with specific antibodies against anti-p60Src (N-16; Santa Cruz), anti-Fyn, or anti-Yes (Transduction, Lexington, KY). For detection of Ret autophosphorylation the cells were lysed and immunoprecipitated as above with a goat anti-Ret antibody, and immune complexes were probed with an anti-phospho-tyrosine antibody (4G10, Upstate Biotechnology).

Western blotting. Neuro2a cells transfected with GFR $\alpha 1$ or SH-SY5Y neuroblastoma cells treated with retinoic acid for $3 \mathrm{~d}$ were stimulated for $10 \mathrm{~min}$ with $30 \mathrm{ng} / \mathrm{ml}$ GDNF. Cerebellar granule cells were maintained for $7 \mathrm{~d}$ in $\mathrm{K} 25+\mathrm{S}$ medium, deprived for $3 \mathrm{hr}$ in $\mathrm{K} 5-\mathrm{S}$, and then stimulated with $\mathrm{K} 25+\mathrm{S}$ for $15 \mathrm{~min}$. When required, a $30 \mathrm{~min}$ preincubation step with the indicated doses of PP2 or PP3 was included before stimulation. Cells then were resuspended in $2 \times$ SDS-Laemmli sample buffer, boiled, and analyzed by immunoblot with an anti-phospho-p42/ p44 MAPK antibody (T202/Y204) or anti-phospho-Akt (Ser-473) (1: 1000; New England Biolabs, Beverly, MA). Blots were stripped in 2\% SDS and $125 \mathrm{~mm}$ Tris, $\mathrm{pH} 6.8$, for $30 \mathrm{~min}$ at $65^{\circ} \mathrm{C}$ and reprobed with an antibody against total MAPK to confirm equal protein loading. Activation of p60Src was monitored with a phospho-specific antibody to Tyr418 on p60Src (Biosource, Camarillo, CA) that is autophosphorylated when Src is activated.

Sympathetic neuronal cultures and treatments. The superior cervical ganglia from P1 Sprague Dawley rats were dissected, dissociated, and seeded onto collagen-coated $35 \mathrm{~mm}$ culture dishes or two-well glass chamber slides (Nunc) as previously described (Martin et al., 1992). Cultures were maintained in vitro (DIV) in medium (90\% MEM, $10 \%$ fetal bovine serum, $2 \mathrm{~mm}$ glutamine, $20 \mu \mathrm{M}$ uridine, $20 \mu \mathrm{M}$ fluorodeoxyuridine, $100 \mathrm{U} / \mathrm{ml}$ penicillin, and $100 \mu \mathrm{g} / \mathrm{ml}$ streptomycin) containing NGF (50 ng/ml, AM50). After $5 \mathrm{~d}$ the cultures were washed twice with medium without NGF (AM0). AM50, anti-NGF (goat polyclonal, 1:10,000 dilution), NGF in the presence of LY294002 or PP2 (50 and 1 $\mu \mathrm{M}$, respectively), NRTN (50 $\mathrm{ng} / \mathrm{ml})$ in the presence of anti-NGF, or NTRN in the presence of anti-NGF with LY294002 or PP2 then was added to the cultures. The neurons were maintained in this medium for $3 \mathrm{~d}$, with one medium replacement after the second day, before fixation and processing for survival assays. Because NRTN supports a higher percentage of survival of SCG neurons, probably reflective of coreceptor expression, NRTN was used rather than GDNF in these survival assays.

Sympathetic neuron survival assays. After the indicated treatments the cultures were washed with ice-cold PBS and fixed for $2 \mathrm{~d}$ with $4 \%$ paraformaldehyde at $4^{\circ} \mathrm{C}$. Then the cultures were washed with deionized water, stained for 45-60 sec in toluidine blue $\mathrm{O}(1 \mathrm{gm} / 1)$, and incubated for an additional $60 \mathrm{sec}$ in deionized water. The cells were dehydrated by using successive 2 min washes in deionized water containing increasing concentrations of ethanol to reach $100 \%$, after which the slides were washed in toluene, and the coverslips were mounted with Permount (Sigma, St. Louis, MO). Neurons displaying smooth cell bodies that were Nissl-stained were considered alive and were counted. Survival counts were obtained in a blinded manner from duplicate wells from three independent cultures.

\section{RESULTS}

\section{Src activity is necessary for GDNF-mediated neurite outgrowth}

To test the functional relevance of SFKs in GDNF-induced neurite outgrowth, we used the selective inhibitor PP2, which inhibits all members of the Src family kinases in the nanomolar range in vitro (Hanke et al., 1996). The structurally related but inactive analog PP3 was used as a negative control in all of these experiments. Neuro2a neuroblastoma cells, which express endogenous Ret but not GFR $\alpha 1$, were cotransfected with either wildtype GFR $\alpha 1$ (GPI-GFR $\alpha 1$ ) or with a chimeric receptor consisting of the extracellular domain of this coreceptor and the transmembrane and cytoplasmic tail of HLA-B44. This transmembrane version of the coreceptor (TM-GFR $\alpha 1$ ) lacks the GPI anchor and therefore does not localize to lipid rafts (Tansey et al., 2000). At 2 d after transfection the cells were switched to GDNFcontaining medium in the presence or absence of PP2, and the number of neurite-bearing cells was counted after a period of 4-5 d. In agreement with our previous results, GDNF elicited a potent neuritogenic response in GPI-GFR $\alpha 1$-transfected cells. The effect was dose-dependent and, at saturating concentrations (30 ng/ml), GDNF supported a four- to sixfold increase in the number of cells with neurites (Fig. 1A). Moreover, the length of neurites was significantly longer in GDNF-treated than in control cells (data not shown). This effect was inhibited significantly by 1 $\mu \mathrm{M}$ PP2, whereas PP3 had no effect (Fig. $1 A$ ). Consistent with our previous work, GFR $\alpha$-TM-expressing cells displayed attenuated 
A

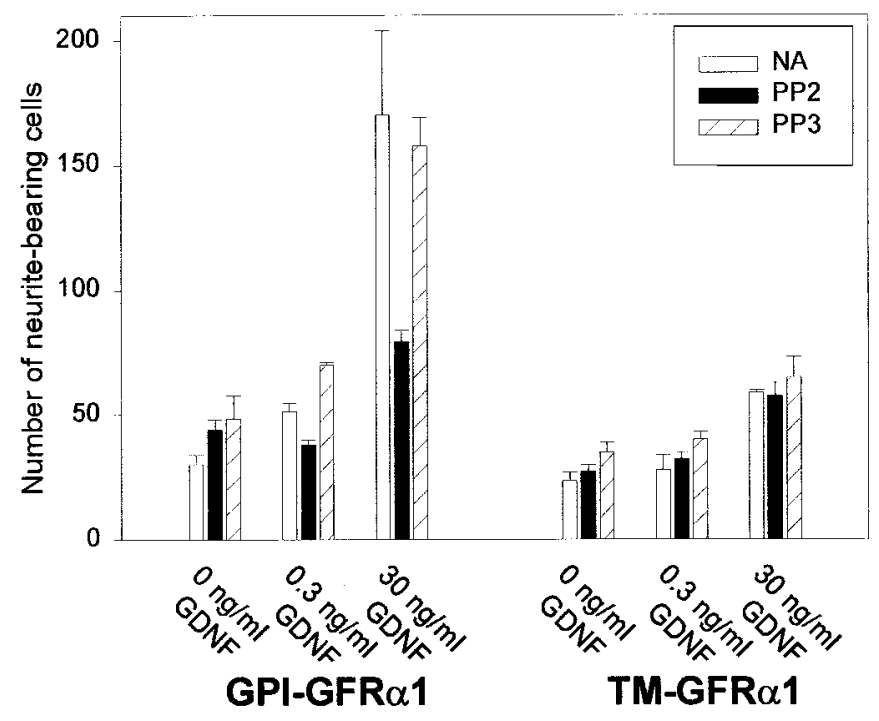

B

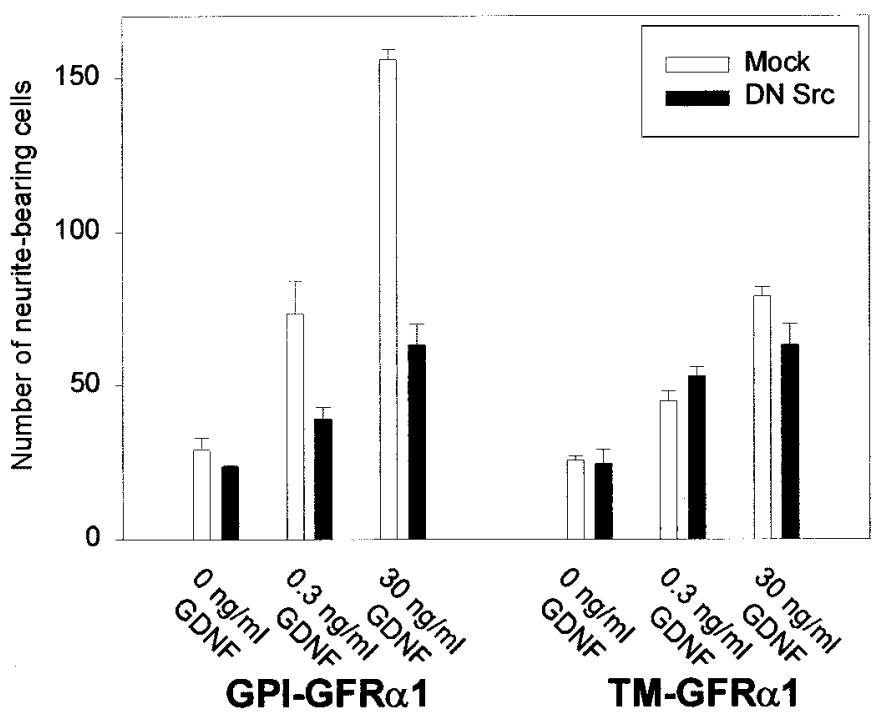

Figure 1. Src activity is necessary for GDNF-mediated neurite outgrowth. $A$, Neuro2a neuroblastoma cells transfected either with the GPIlinked or the transmembrane (TM) version of GFR $\alpha 1$ were treated with GDNF in the presence of the SFK inhibitor PP2 $(1 \mu \mathrm{M})$, the structurally related but inactive analog PP3 $(1 \mu \mathrm{M})$, or neither $(N A)$. After 4 DIV the cells with neurites longer than two cell bodies were counted as described in Materials and Methods. $B$, Neuro2a cells were cotransfected with either the GPI-linked or the transmembrane (TM) version of GFR $\alpha 1$ and either a plasmid coding for a dominant-negative mutant of $\operatorname{Src}(D N S r c)$ or the empty expression vector (Mock). Cells were treated with the indicated concentrations of GDNF, and neurite outgrowth was assessed as in $A$. Each condition was performed in triplicate. The results shown represent the means $\pm \operatorname{SEM}(n=3)$.

neurite outgrowth in response to GDNF; however, PP2 did not affect the GDNF-induced neurite outgrowth in these cells.

To test further the hypothesis that SFKs are important in GDNF-induced responses, we cotransfected Neuro2a cells with a dominant-negative mutant of Src and either the GPI or the TM version of GFR $\alpha 1$. This dominant-negative Src most likely acts as a pan-Src inhibitor because it encodes both K296R and Y528F mutations and, therefore, is able to bind to phosphotyrosine docking sites, but it is unable to phosphorylate downstream targets (Courtneidge et al., 1993). Again, only the GPI-GFR $\alpha 1$ expressing cells showed a robust neuritogenic response to GDNF, whereas this biological effect was attenuated in TM-GFR $\alpha 1$ transfected cells. Consistent with the results obtained with PP2, inhibition of SFK activity by the dominant-negative construct resulted in a significant reduction in the number of neuritebearing cells as compared with the mock-transfected cells (Fig. $1 B$ ). This reduction was not observed in the TM-expressing cells, consistent with the fact that Ret is not able to interact with SFK when activated by the transmembrane version of GFR $\alpha 1$ (Tansey et al., 2000). Taken together, these data indicate that SFK activity was necessary for GDNF-mediated neurite outgrowth via wildtype Ret-GFR $\alpha 1$.

\section{SFK activity is necessary for GDNF-mediated neuronal survival}

We also investigated whether SFK activity was necessary for another Ret-mediated function, neuronal survival. To test this hypothesis, we used cerebellar granule cells (CGCs), which survive in a medium containing high potassium $(25 \mathrm{~mm})$ plus serum $(\mathrm{K} 25+\mathrm{S})$ but undergo apoptosis in low potassium $(5 \mathrm{~mm})$ medium without serum (K5-S) (D'Mello et al., 1993). Cultured cerebellar granule cells do not express either Ret or any of the GFR $\alpha$ coreceptors, allowing for reconstitution of this receptor system by transfection with defined (wild-type or mutant) components (M. Tansey and E. M. Johnson, unpublished observations). As expected, cotransfection of Ret and GFR $\alpha 1$ is sufficient to elicit a dose-dependent increase in GDNF-mediated cell survival (Tansey et al., 2000). Concentrations as low as $0.3 \mathrm{ng} / \mathrm{ml}$ of GDNF in K5-S medium supported $\sim 30 \%$ maximum survival; the effect was maximal at $30 \mathrm{ng} / \mathrm{ml}$, reaching levels comparable with those obtained in $\mathrm{K} 25+\mathrm{S}$ medium (Fig. $2 A$ ). However, the addition of $\mathrm{PP} 2$, but not PP3, to the GDNF-containing medium significantly inhibited the survival-promoting effect. In contrast, PP2 did not have any effect on the survival elicited by $\mathrm{K} 25+\mathrm{S}$ medium, indicating that the cell death observed in the presence of this compound was not caused by nonspecific toxicity. Furthermore, SFK activity was not required for the survival-promoting activity of depolarization and serum (Fig. 2A). Consistent with this finding, depolarization-induced MAPK (data not shown) and Akt phosphorylation were unaffected by the addition of PP2 (Fig. 2C), although they were affected by LY294002 treatment. Similar effects on survival were obtained when a plasmid coding for a dominant-negative form of Src was used instead of PP2 (Fig. 2B). Moreover, PP2 also inhibited GDNF-mediated survival in rat sympathetic neurons, which express both Ret and GFR $\alpha 1$ (see below).

\section{p60Src, but not Fyn or Yes, interacts with activated Ret}

We and others have demonstrated previously that activated Ret interacts with a member or members of the SFK (Melillo et al., 1999; Tansey et al., 2000). In particular, we have detected pan-Src immunoreactivity in Ret immunoprecipitates only when the activated Ret complex is associated with lipid rafts. Moreover, a Src-SH2 probe is able to precipitate Ret in GDNF-stimulated, but not control, Neuro2a lysates (Tansey et al., 2000). A critical question was to determine which members of the SFKs interact with Ret under these conditions. To address this, we performed Ret coimmunoprecipitation experiments in Neuro2a cells transfected either with the GPI-GFR $\alpha 1$ or the TM-GFR $\alpha 1$ and stim- 
ulated with GDNF. Then the immune complexes were resolved by SDS-PAGE and probed with specific antibodies against p60Src, Fyn, and Yes, the three ubiquitous SFKs (Thomas and Brugge, 1997). As shown in Figure $3 A$, p60Src was found to be associated with Ret only in GDNF-stimulated cells expressing GPI-GFR $\alpha 1$. However, neither Fyn nor Yes was associated significantly with Ret under any of the experimental conditions (Fig. $3 B, C)$. Only small amounts of Fyn and Yes immunoreactivity were detected after longer exposures of the film but were negligible when compared with the amount of these proteins in total extracts, indicating that only a minor fraction of these proteins was associated with the activated receptor complex (Fig. 3B,C). To test whether an association between Ret and p60Src also occurred in rat sympathetic neurons, we stimulated SCG neurons with GDNF, immunoprecipitated Ret, and subjected the immune complexes to p60Src immunoblotting. Similar to Neuro2a cells, p60Src coimmunoprecipitated with Ret only in GDNFstimulated extracts from SCG neurons, suggesting that this association was phosphotyrosine-dependent. In contrast, neither Fyn nor Yes coimmunoprecipitated with Ret (Fig. 3D) despite the fact that significant levels of these proteins were detected in total lysates from these neurons. Thus, the effects of PP2 and dominant-negative mutants of Src on neuronal differentiation and survival were attributable primarily to the inhibition of p60Src, but not Fyn or Yes, activity.

\section{p60Src becomes activated after GDNF stimulation}

The ability of the $\mathrm{SH} 2$ domain of Src to precipitate Ret in a phosphotyrosine-dependent manner (Tansey et al., 2000) suggests that the interaction of Ret with Src may activate Src kinase activity. Intramolecular interactions between the $\mathrm{SH} 2$ domain and the phosphorylated tail of SFKs maintain their inactive or "closed" conformation. Displacement of this interaction by SH2-binding phosphotyrosines in activated receptors leads to SFK activation (Thomas and Brugge, 1997; Abram and Courtneidge, 2000). To address whether GDNF can activate Src tyrosine kinase activity, we immunoprecipitated Ret from GPI- or TM-GFR $\alpha$-expressing Neuro2a cells, and we probed immune complexes with an antibody that specifically recognizes Src only when it is phosphorylated in tyrosine 418. This residue, located in the Src tyrosine kinase domain, is autophosphorylated when Src is activated (Abram and Courtneidge, 2000). As shown in Figure 4, Src became phosphorylated on Tyr-418 only in GDNF-stimulated, wild-type GFR $\alpha 1$ expressing cells, indicating that only in this condition was Src activated. Thus, as expected, the interaction of Ret with Src led to the activation of the tyrosine kinase activity of Src.

\section{The SFK inhibitor PP2 blocks GDNF-mediated Akt and MAPK phosphorylation}

The decreased ability of nonraft-associated Ret to promote differentiation and survival of a mislocalized Ret correlates with diminished downstream signaling, as measured by Akt and MAPK phosphorylation (Tansey et al., 2000). Therefore, we investigated whether Src inhibition also resulted in decreased phosphorylation of these signaling molecules. Neuro2a cells transfected with wild-type GFR $\alpha 1$ were stimulated with GDNF in the presence of PP2 or PP3, and the amount of phosphorylated Akt and MAPK was assessed by using phospho-specific antibodies. PP2, but not PP3, inhibited both Akt and MAPK phosphorylation in GPI-GFR $\alpha 1$-transfected cells (Fig. $5 A$ ). Note that $1 \mu \mathrm{M}$ PP2 produced significant, but not complete, inhibition of GDNFinduced Akt phosphorylation (see below). As expected, the induction of phosphorylation of both Akt and MAPK in TM-
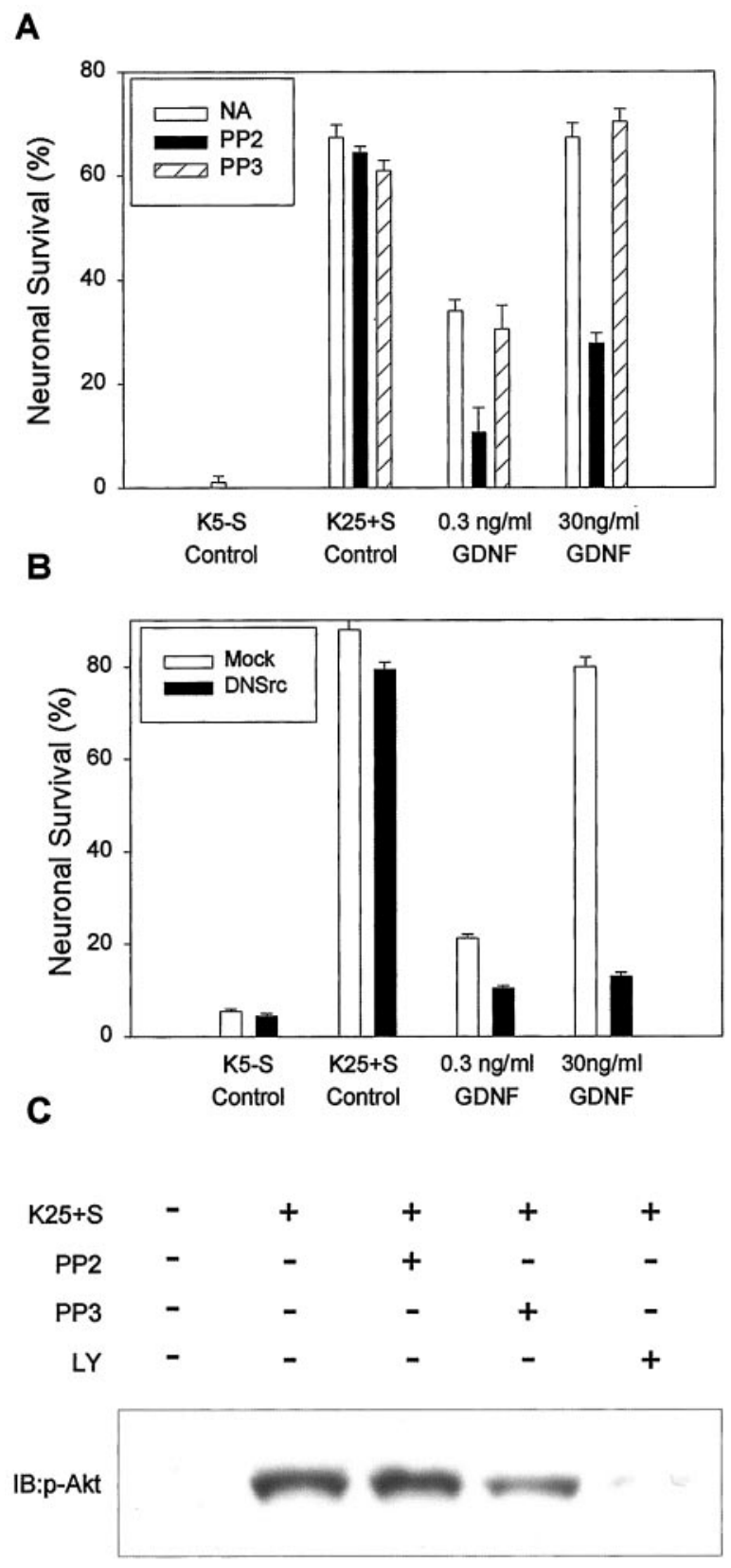

Figure 2. Inhibition of Src activity results in the blockade of GDNFmediated survival. Cerebellar granule cells (CGCs) were transfected with Ret and wild-type GFR $\alpha 1$. At $2 \mathrm{~d}$ after transfection the cells were switched to $\mathrm{K} 5-\mathrm{S}$ medium containing increasing concentrations of GDNF or vehicle alone $(N A)$, PP2 $(1 \mu \mathrm{M})$, or PP3 $(1 \mu \mathrm{M})$. Neuronal survival was evaluated after $48 \mathrm{hr}$ in culture as described in Materials and Methods. Each condition was performed in duplicate. The results shown represent the means $\pm \operatorname{SEM}(n=4)$. $B$, CGCs were cotransfected with Ret and wild-type GFR $\alpha 1$ and either a dominant-negative Src mutant $(D N S r c)$ or the corresponding empty expression plasmid (Mock). After $48 \mathrm{hr}$ in culture, cell survival was evaluated as in $A$. $C$, Depolarizationinduced Akt phosphorylation in CGC is unaffected by PP2. Cerebellar granule cells were maintained in $\mathrm{K} 25+\mathrm{S}$ medium for $7 \mathrm{~d}$, deprived for 3 $\mathrm{hr}$ in $\mathrm{K} 5-\mathrm{S}$, and then stimulated for $15 \mathrm{~min}$ with $\mathrm{K} 25+\mathrm{S}$. Where indicated, a preincubation step with either PP2 or PP3 (both at $1 \mu \mathrm{M}$ ) or LY294002 $(30 \mu \mathrm{M})$ was included before stimulation. Whole-cell lysates were probed with anti-phospho-Akt antibodies as described in Materials and Methods. Equal amounts of protein were loaded in each condition. The data shown are representative of two independent experiments. 
A

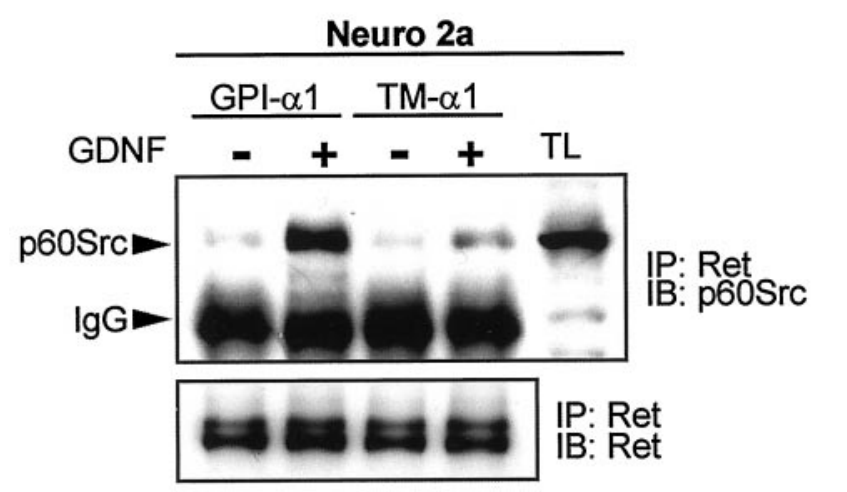

B

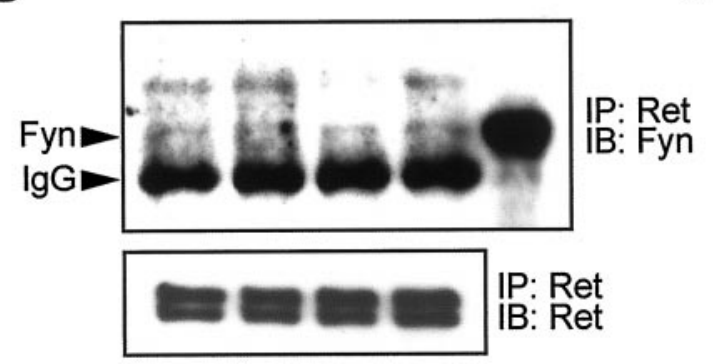

E

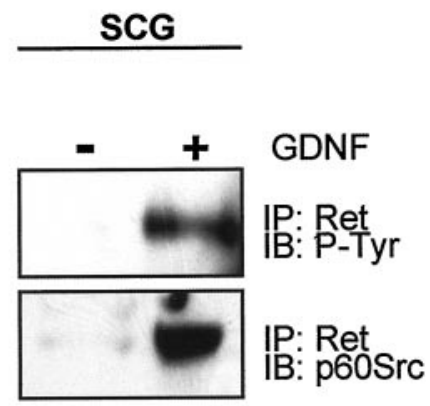

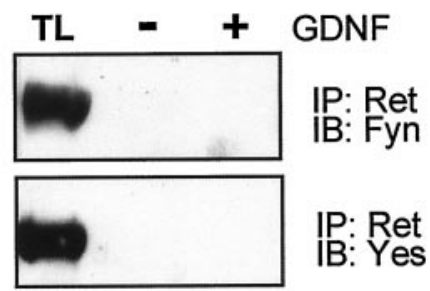

Figure 3. p60Src, but not Fyn or Yes, associates with activated Ret. $A$, Neuro2a cells transfected with either the GPI-GFR $\alpha 1$ or the TM-GFR $\alpha 1$ were stimulated with 30 ng/ml GDNF, Ret was immunoprecipitated, and immune complexes were probed with a specific anti-p60Src antibody (top panel). The TL lane $(T L)$ corresponds to an aliquot of total lysate removed before immunoprecipitation, representing $10 \%$ of the protein that was immunoprecipitated. The bottom panel shows an immunoblot against Ret from the same membrane to assess the quantitative immunoprecipitation of the receptor. $B$, Lysates treated as in $A$ were probed with an anti-Fyn antibody. $C$, Lysates treated as in $A$ were probed with an anti-Yes antibody. $D$, p60Src coimmunoprecipitates with phosphorylated Ret in sympathetic neurons. Superior cervical ganglion cells were stimulated with $30 \mathrm{ng} / \mathrm{ml} \mathrm{GDNF}$, and Ret was immunoprecipitated. Ret phosphorylation was determined by probing immune complexes with an anti-phospho-tyrosine antibody $(P-T y r ; t o p)$; whether Src coimmunoprecipitates was determined by probing these immune complexes with an anti-p60Src antibody (bottom). E, Superior ganglion cells treated as in $D$, but Ret immunoprecipitates were probed with either anti-Fyn or anti-Yes antibodies. A whole-cell lysate $(T L)$ was included to show the migration of these species. IP, Immunoprecipitation; $I B$, immunoblot.
C

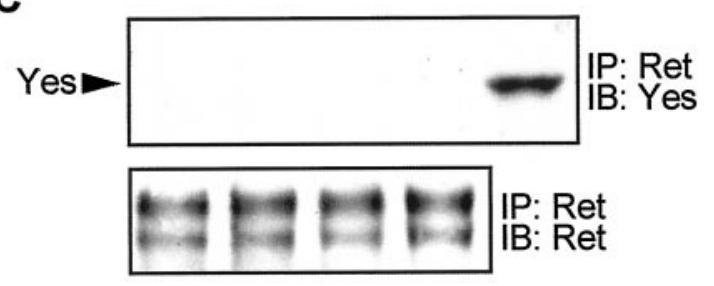

expressed cells was attenuated but was not affected by PP2 or PP3 (data not shown), consistent with the fact that the activated Ret complex in GFR $\alpha 1$-TM-expressing cells is not in lipid rafts and, therefore, does not interact with SFKs (Tansey et al., 2000). We also tested the effect of PP2 in the SH-SY5Y neuroblastoma cell line, which expresses Ret and GFR $\alpha 1$ after exposure to retinoic acid. As shown in Figure 5B, PP2 caused a dose-dependent decrease in the state of phosphorylation of both Akt and MAPK, suggesting that the involvement of SFKs in GDNF-mediated signaling was a generalized event.

Because PP2 is able to inhibit EGFR directly, although with a 100-fold higher IC $_{50}$ than SFKs (Hanke et al., 1996), we tested whether PP2 was eliciting the observed effects via SFK inhibition or via a direct inhibition of the kinase activity of Ret. Neuro2a cells transfected with the GPI version of GFR $\alpha 1$ were stimulated with GDNF in the presence of $1 \mu \mathrm{M}$ PP2 or PP3, Ret was immunoprecipitated, and the level of tyrosine phosphorylation was analyzed by Western blotting. The addition of PP2 had a negligible effect on the autophosphorylation of Ret (Fig. 5C), which was not likely to account for the inhibitory effects of PP2 on downstream signaling and bioactivity. Higher concentrations (5 $\mu \mathrm{M})$ of PP2, however, significantly inhibited Ret phosphorylation (see below).

\section{GDNF-dependent survival of granule neurons requires PI-3K and Src activities}

The PI-3K/Akt pathway has a pivotal role in cerebellar granule neuron survival (D’Mello et al., 1997; Dudek et al., 1997; Miller et al., 1997). To test whether PI-3K activity was necessary for GDNF-mediated survival, we maintained Ret- and GFR $\alpha 1$ expressing granule cells in the presence of the PI-3K-selective

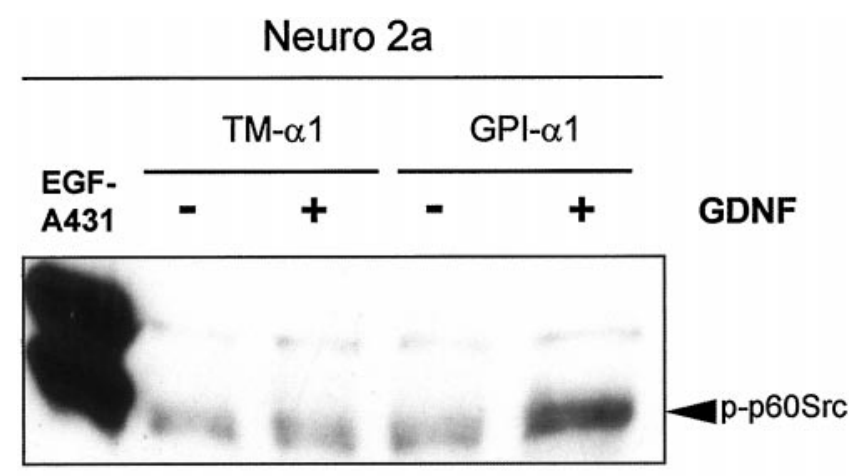

IB:pY-418-Src

Figure 4. Src becomes activated after GDNF stimulation in GPIGFR $\alpha 1$-expressing, but not TM-GFR $\alpha 1$-expressing, cells. Neuro2a cells were transfected with the indicated constructs and stimulated with GDNF (30 ng/ml; $10 \mathrm{~min}$ ). Ret was immunoprecipitated, and immune complexes were probed with a phospho-specific antibody against the Tyr-418 of Src. This residue is the major autophosphorylation tyrosine in Src, and its phosphorylation correlates with the kinase activity. As a positive control a lysate from A431 cells stimulated with EGF was included (left lane). The data shown are representative of two independent experiments. 
inhibitor LY294002 (30 $\mu \mathrm{M})$. This inhibitor completely prevented the survival-promoting activity of GDNF, indicating that PI-3K activity was necessary for GDNF-induced survival of these cells (Fig. 6). To investigate further whether Src was promoting cell survival via a PI-3K-dependent pathway or whether both PI-3K and Src contributed to this biological effect via independent mechanisms, we transfected granule cells with a constitutively active mutant of Src (CA Src). As shown in Figure 6, this mutant was able to promote a partial rescue in the absence of any trophic
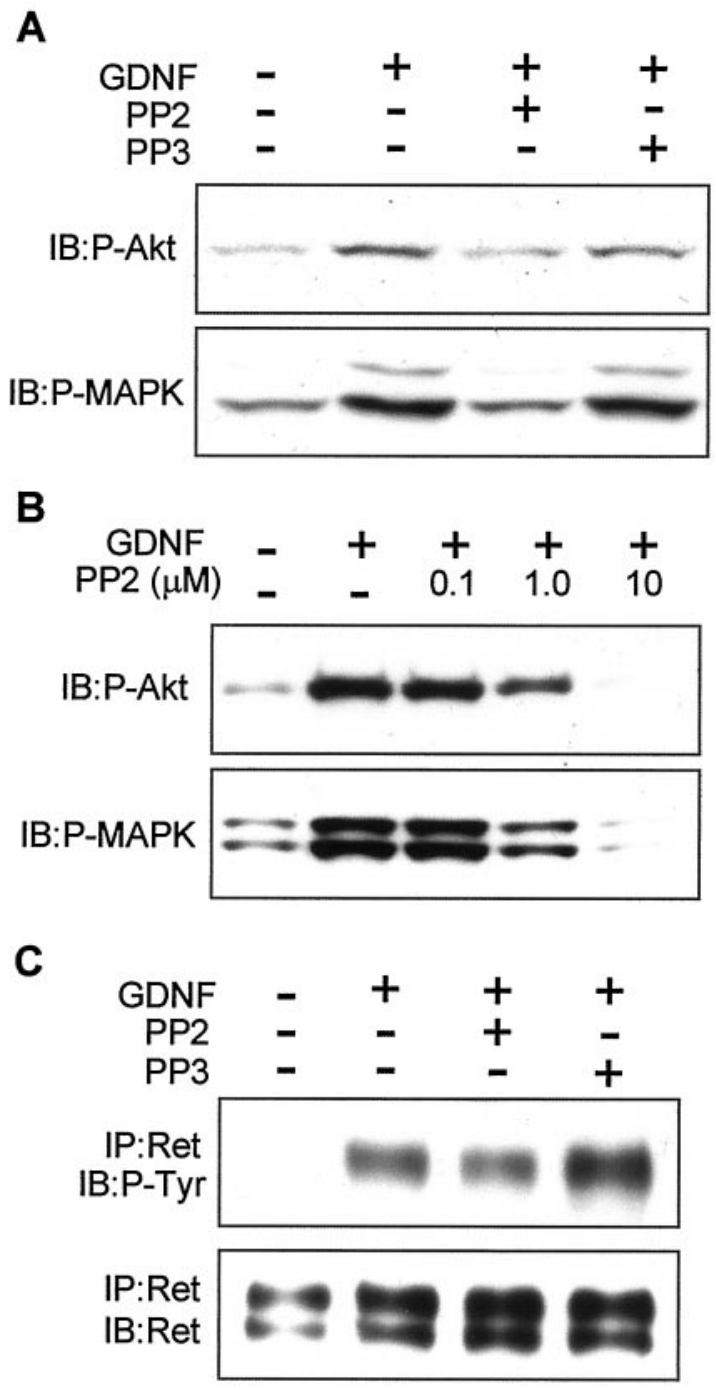

Figure 5. The SFK inhibitor PP2 blocks distal, but not proximal, GDNFmediated signaling. $A$, Neuro2a cells transfected with GFR $\alpha 1$ were stimulated with $30 \mathrm{ng} / \mathrm{ml}$ GDNF for $10 \mathrm{~min}$. When indicated, the cells were preincubated with either PP2 or PP3 $(1 \mu \mathrm{M})$ for $30 \mathrm{~min}$. Then total lysates were resolved by SDS-PAGE and probed with phospho-specific antibodies against Akt and MAPKs. $B$, SH-SY5Y cells, which endogenously express both Ret and GFR $\alpha 1$ after retinoic acid treatment, were stimulated with GDNF and increasing concentrations of PP2. Total lysates were resolved by SDS-PAGE and probed with phospho-specific antibodies against Akt and MAPKs. The data shown are representative of two to three independent experiments. $C$, Neuro2a cells transfected with wild-type GFR $\alpha 1$ were stimulated with $30 \mathrm{ng} / \mathrm{ml} \mathrm{GDNF}$ for $10 \mathrm{~min}$. When indicated, the cells were incubated with PP2 or PP3 $(1 \mu \mathrm{M})$ for 30 min before stimulation. Ret was immunoprecipitated, and the level of autophosphorylation was assessed by Western blot (top). The filter was stripped and reprobed with anti-Ret antibody to assess equal protein loading of the lanes (bottom). IP, Immunoprecipitation; $I B$, immunoblot.

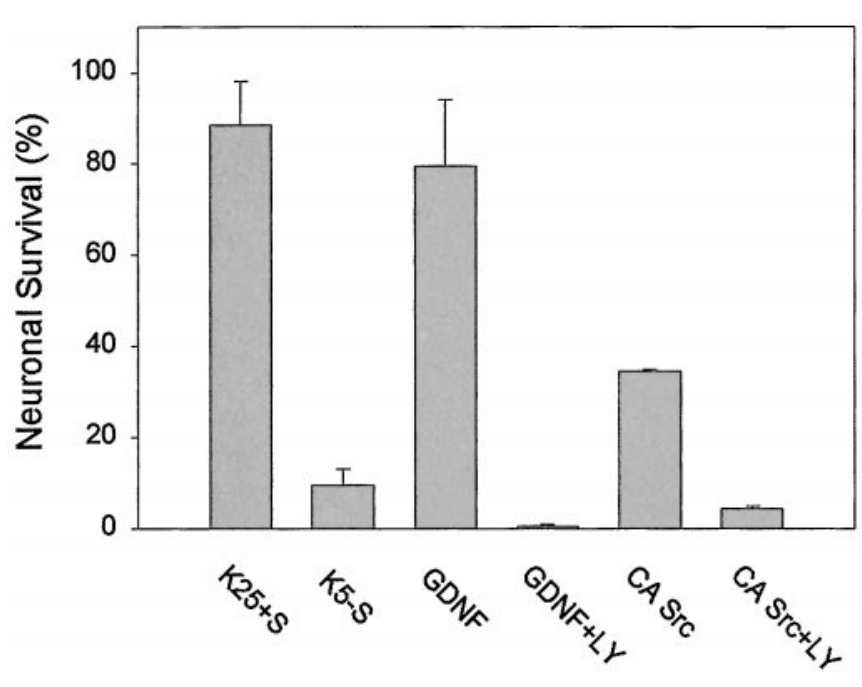

Figure 6. Src promotes CGC survival via a PI-3K-dependent mechanism. CGCs either were cotransfected with Ret and GFR $\alpha 1$ or were transfected with a constitutively active mutant of Src alone $(C A S r c)$. In the first case the cells were maintained with $\mathrm{K} 25+\mathrm{S}, \mathrm{K} 5-\mathrm{S}$, or $\mathrm{K} 5-\mathrm{S}$ containing $30 \mathrm{ng} / \mathrm{ml}$ GDNF alone or in combination with $30 \mu \mathrm{M}$ LY294002. Cells transfected with CA Src were maintained in $\mathrm{K} 5-\mathrm{S}$ medium alone or $\mathrm{K} 5-\mathrm{S}$ containing $30 \mu \mathrm{M}$ LY294002. After $2 \mathrm{~d}$ in culture, cell survival was assessed as described in Materials and Methods. Each condition was performed in duplicate. The results shown represent the means $\pm \operatorname{SEM}(n=3)$.

support, but this rescue was prevented completely by LY294002. The inability of CA Src to promote survival as efficiently as GDNF may reflect the lack of scaffolding and membrane localization provided by association with the Ret signaling complex, or it may be attributable to the requirement of additional GDNFactivated signaling molecules upstream of PI-3K. This observation, together with the reduction of Akt phosphorylation by PP2 (see Fig. 5), suggests that Src maintained cell survival by modulating the activation of the PI-3K/Akt pathway.

\section{Src activity is necessary for GFL-mediated, but not NGF-mediated, survival of granule and sympathetic neurons}

We next investigated whether the requirement for SFK activity in survival promotion was specific to Ret-mediated survival or also was involved in TrkA-mediated survival. Granule cells transfected with TrkA did survive in $\mathrm{K} 5-\mathrm{S}$ medium supplemented with NGF. However, PP2 did not affect NGF/TrkA-mediated survival (Fig. $7 A$ ), suggesting that SFKs do not have a major role in survival promotion by this neurotrophic factor.

To determine whether primary neurons that normally express Ret and GFR $\alpha$ s required Src and PI-3K activities for GFLdependent survival, we examined the NRTN-mediated survival of sympathetic neurons from the superior cervical ganglion. After being maintained in NGF for 5 DIV, sympathetic neurons were switched to medium containing NRTN in the presence or absence of LY294002 or PP2. Compared with NGF, NRTN saved $\sim 50 \%$ of the neurons after $3 \mathrm{~d}$, in contrast to neurons that had been switched to medium containing no factors (Fig. 7B). Inhibition of PI-3K with LY294002 completely blocked the NRTNdependent survival. In contrast, PI-3K inhibition had only modest effects on NGF-mediated survival. In fact, NRTN-maintained neurons treated with LY294002 died with the same time course as NGF deprivation, suggesting that PI-3K completely accounted for the survival-promoting ability of NRTN on sympathetic neurons. 
A

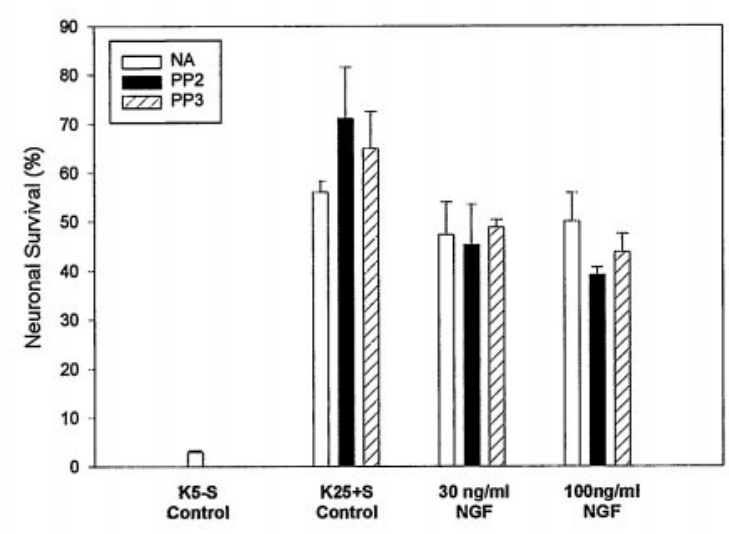

\section{B}

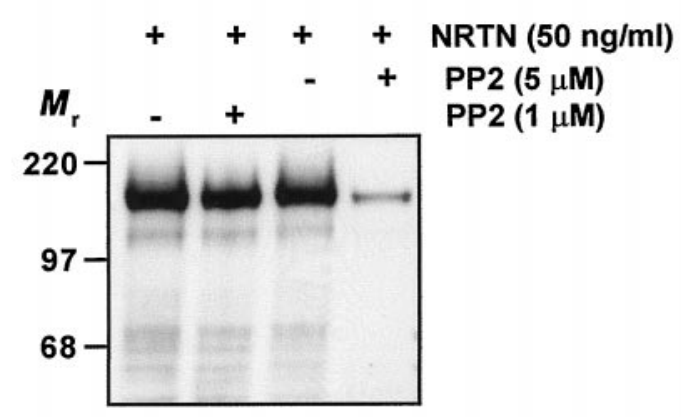

C

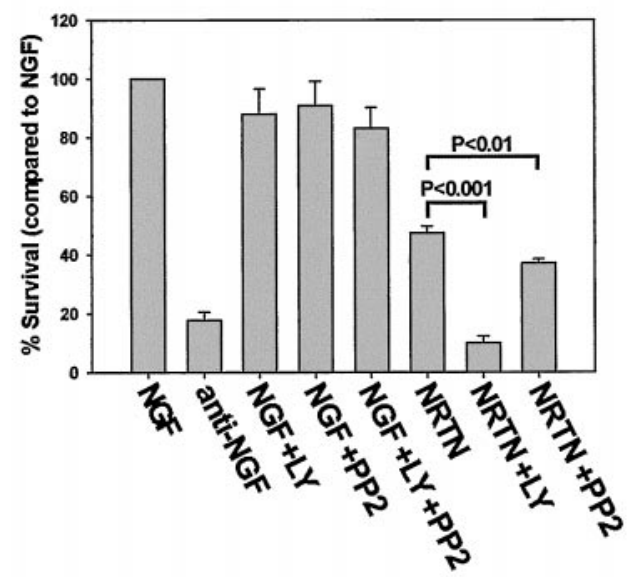

Figure 7. The SFK inhibitor PP2 blocks GFL-mediated, but not NGFmediated, neuronal survival. $A$, Cerebellar granule cells transfected with TrkA were maintained in $\mathrm{K} 5-\mathrm{S}$ medium containing increasing concentrations of NGF in the presence or the absence of either PP2 or PP3 (1 $\mu \mathrm{M})$. Neuronal survival was assessed after $48 \mathrm{hr}$ in culture as described in Materials and Methods. Each condition was performed in duplicate. The results shown represent the means $\pm \operatorname{SEM}(n=3)$. $N A$ designates no addition of PP2 or PP3. B, Sympathetic neurons (5 DIV) were deprived of NGF for $7 \mathrm{hr}$ and then treated with medium containing NRTN $(50 \mathrm{ng} / \mathrm{ml})$
Src inhibition with $1 \mu \mathrm{M}$ PP2 also decreased NRTN-mediated survival $(p<0.01)$, in contrast to NGF-dependent survival in which PP2 had no effect (Fig. 7B). As in granule neurons, treatment with PP2 $(1 \mu \mathrm{M})$ had little effect on Ret phosphorylation (Fig. 7C), although higher doses of PP2 (5 $\mu \mathrm{M})$ were more effective in blocking Ret activation. Because sympathetic neurons were treated with only $1 \mu \mathrm{M}$ PP2 to avoid substantial inhibition of Ret itself, Src activity was not inhibited completely (data not shown) at this concentration in sympathetic neurons, similar to SY5Y cells (see Fig. 5B), leading to less death than was observed in granule neurons. In this regard, $1 \mu \mathrm{M}$ PP2 did not prevent GDNF-mediated survival in CGCs completely as compared with the dominant-negative mutant of Src (see Fig. $2 A, B$ ), indicating that the inhibitor did not block Src activity completely. In conclusion, consistent with data from granule neurons, GFLs promoted survival in sympathetic neurons via activation of PI-3K in a, at least partially, Src-dependent manner.

\section{DISCUSSION}

In a previous study we demonstrate that localization of Ret to lipid rafts is necessary for optimal GFL-mediated differentiation and survival responses as well as for maximal downstream signaling. One suggested explanation for this observation is the requirement of important protein-protein interactions between Ret and raft-associated signaling molecules to elicit full GFLmediated responses. In particular, SFKs interact with Ret only when the receptor is localized in these membrane microdomains (Tansey et al., 2000). In the present work we showed that SFK activity was necessary for both differentiation and survival events elicited by GFLs, indicating that this interaction was biologically important. Moreover, the reduced bioactivity observed after SFK inhibition (achieved by two independent approaches) correlated with a decrease in the state of activation of both Akt and MAPK pathways, providing a possible mechanism by which Src could be driving these biological effects. We identified p60Src as the specific member of the SFK that interacted with activated Ret. Interaction with Ret correlated with the activation of p60Src, as measured by phosphorylation of Src at Tyr-418. The survivalpromoting effects of Src were mediated via a PI-3K-dependent mechanism, because LY294002 blocked GFL-activated and activated Src-dependent cell survival in multiple neuronal types. Finally, Src was involved in GFL-mediated, but not NGFmediated, neuronal survival in two different primary cultures, suggesting that the families of factors use different pathways to promote neuronal survival. In summary, these data indicate that Src was a key proximal-signaling molecule in the transduction cascades initiated by GFLs and provide an explanation as to why compartmentalized signaling in lipid rafts was necessary to achieve efficient neuronal survival and neurite outgrowth.

or medium containing NRTN in the presence of 1 or $5 \mu \mathrm{M}$ PP2. Neurons treated with 1 or $5 \mu \mathrm{M} \mathrm{PP} 2$ and NRTN also were pretreated with that same concentration of PP2 for 30 min before the NRTN addition. The cultures were washed, Ret was immunoprecipitated from each condition, and the immunoprecipitates were subjected to phosphotyrosine immunoblotting. $C$, Sympathetic neurons (5 DIV) were deprived of NGF, maintained in NGF alone or in the presence of LY294002 $(50 \mu \mathrm{M})$, PP2 $(1 \mu \mathrm{M})$, or both, or switched to medium containing NRTN $(50 \mathrm{ng} / \mathrm{ml})$ alone or in the presence of LY294002 or PP2. The sympathetic neurons were maintained for an additional $3 \mathrm{~d}$, with one medium change, after which they were fixed and toluidine blue $\mathrm{O}$-stained; the number of surviving neurons was determined in a blinded manner. 


\section{Role of Src in cellular differentiation}

The first biological effect modulated by Src activity that we measured was neurite outgrowth. The addition of PP2 or transfection with a dominant-negative form of p60Src markedly reduced the number of neurite-bearing cells. Inhibition of Src did not affect TM-driven differentiation, indicating that the role of Src was to enhance rather than to mediate entirely the neuritepromoting effect of GDNF. Thus, one hypothesis was that the differences between GPI- and TM-induced differentiation were attributed almost exclusively to the presence or the absence of Src activity, i.e., in the localization, or not, of the activated Ret/ GFR $\alpha$ complex to lipid rafts.

The role of Src in cellular differentiation has been investigated primarily by infection with the Rous sarcoma virus (RSV), which expresses the oncogenic variant $v$-Src. These studies reveal that the function of Src on differentiation depends mainly on the cellular context. In many cell types such as avian myoblasts, retinoblasts, or chondroblasts, expression of $v$-Src results in the abrogation of differentiation responses (Muto et al., 1977; Yoshimura et al., 1981; Crisanti-Combes et al., 1982; Alema and Tato, 1987). In some neuronal cell types, however, expression of $v$-Src induces differentiation. Avian sympathetic neuroblasts infected with RSV stop proliferating and differentiate by extending neurites and expressing neuronal markers (Haltmeier and Rohrer, 1990). In PC12 pheochromocytoma cells the expression of $v$-Src causes morphological differentiation that mimics the effects of NGF by different criteria (Alema et al., 1985; Thomas et al., 1991). Thus, the effects of overexpression of the viral form of Src may not necessarily reflect an involvement of its cellular counterpart $c$-Src in neuronal differentiation.

\section{Src promotes neuronal survival via a PI-3K-dependent pathway}

In contrast to the well established roles of Src in cell cycle control, cell movement and adhesion, and cell differentiation (Thomas and Brugge, 1997), the role of Src in survival has remained elusive. Early experiments performed with $v$-Src reveal that its expression in certain cell types rescues these cells from apoptosis that is induced by cytokine withdrawal (Anderson et al., 1990; McCubrey et al., 1993) and the loss of extracellular matrix adhesion (Frisch and Francis, 1994). The role of the cellular homolog $c$-Src, however, is less well documented. Perhaps the most compelling evidence for the involvement of $c$-Src in cell survival comes from a recent report by Wong et al. (1999). In this work osteoclasts derived from $\mathrm{Src}^{-1-}$ mice show an impaired TRANCE-mediated survival response with respect to wild-type osteoclasts. Interestingly, this reduction in survival correlates with a decreased ability of TRANCE to activate the Ser/Thr kinase Akt, the anti-apoptotic function of which is well established (for review, see Datta et al., 1999). This finding extended to IL-1- and LPS-induced Akt activation, suggesting that the mechanism may represent a general pathway in cytokinemediated survival (Wong et al., 1999). Thus, Src may activate PI-3K that, in turn, activates Akt and ultimately promotes cell survival (see Schlessinger, 2000). Consistent with this hypothesis, our results show that $\mathrm{Src}$ inhibition resulted in a blockade of Akt phosphorylation and marked attenuation of neuronal survival induced by GFLs. Accordingly, in our model the PI-3K inhibitor LY294002 abolished GDNF- and NRTN-mediated survival in granule and sympathetic neurons, respectively. Therefore, we speculate that the survival-promoting effects of GFLs likely were mediated through p60Src via the PI3K pathway. Consistent with this model, we found that a constitutively active mutant of Src partially rescued CGCs from death in $\mathrm{K} 5-\mathrm{S}$ medium and that this effect was blocked completely by the PI-3K inhibitor LY294002, suggesting that the survival-promoting effects of Src were mediated principally by PI-3K. The relevance of the PI-3K/ Akt pathway in GDNF-mediated survival occurs in other neuronal models such as spinal cord motor neurons (Soler et al., 1999). Consistent with this, sympathetic neurons were completely dependent on PI-3K for the survival-promoting effects of NRTN. This is in contrast to NGF-mediated survival of sympathetic neurons, which rely on additional signaling pathways in conjunction with PI-3K for survival (Philpott et al., 1997; Virdee et al., 1999; Tsui-Pierchala et al., 2000). Thus, signaling pathways mediating survival are not only cell type-specific, but in neurons they may also be growth factor- and receptor-specific.

\section{Specificity of Ret-SFK interactions}

The selectivity of the interaction between Ret and p60Src, but not Fyn or Yes, perhaps was somewhat surprising, given the high degree of functional redundancy that analysis of mice deficient in these proteins has revealed (for review, see Lowell and Soriano, 1996). However, the specificity of protein-protein interactions between a given member of the SFK and certain receptors is not unprecedented. For example, Lyn interacts specifically with FceRI in basophils (Sheets et al., 1999), and LAT (linker of activation of $\mathrm{T}$ cells) specifically binds to the $\mathrm{T}$ cell receptor (TCR) (Harder and Simons, 1999; Janes et al., 1999). Moreover, similar cellular functions may be mediated by different SFKs depending on cell type, as is the case for Fyn, but not Src or Yes, in the morphological differentiation of oligodendrocytes (Osterhout et al., 1999). Thus, although p60Src was the major target for activated Ret in sympathetic neurons and Neuro2a neuroblastoma cells, other SFKs might have interacted with Ret, depending on the cellular context. Finally, our work supports a model in which the requirement for SFK activity is specific for GFL/Retmediated neuronal survival and suggests that SFK members are unlikely to have a central function in survival responses elicited by NGF/TrkA signaling.

\section{REFERENCES}

Abram CL, Courtneidge SA (2000) Src family tyrosine kinases and growth factor signaling. Exp Cell Res 254:1-13.

Airaksinen MS, Titievsky A, Saarma M (1999) GDNF family neurotrophic factor signaling: four masters, one servant? Mol Cell Neurosci 13:313-325.

Alema S, Tato F (1987) Interaction of retroviral oncogenes with the differentiation program of myogenic cells. Adv Cancer Res 49:1-28.

Alema S, Cassalbore P, Agostini E, Tato F (1985) Differentiation of PC12 pheochromocytoma cells induced by $v$-src oncogene. Nature 316:557-559.

Anderson RG (1998) The caveolae membrane system. Annu Rev Biochem 67:199-225.

Anderson SM, Carroll PM, Lee FD (1990) Abrogation of IL-3dependent growth requires a functional $v$-src gene product: evidence for an autocrine growth cycle. Oncogene 5:317-325.

Baloh RH, Tansey MG, Lampe PA, Fahrner TJ, Enomoto H, Simburger KS, Leitner ML, Araki T, Johnson Jr EM, Milbrandt J (1998) Artemin, a novel member of the GDNF ligand family, supports peripheral and central neurons and signals through the GFR $\alpha 3$-RET receptor complex. Neuron 21:1291-1302.

Baloh RH, Enomoto H, Johnson Jr EM, Milbrandt J (2000) The GDNF family ligands and receptors-implications for neural development. Curr Opin Neurobiol 10:103-110.

Brown DA, London E (1998) Functions of lipid rafts in biological membranes. Annu Rev Cell Dev Biol 14:111-136.

Brown DA, London E (2000) Structure and function of sphingolipidand cholesterol-rich membrane rafts. J Biol Chem 275:17221-17224.

Buj-Bello A, Buchman VL, Horton A, Rosenthal A, Davies AM (1995) GDNF is an age-specific survival factor for sensory and autonomic neurons. Neuron 15:821-828. 
Cacalano G, Fariñas I, Wang L-C, Hagler K, Forgie A, Moore M, Armanini M, Phillips H, Ryan AM, Reichardt LF (1998) GFR $\alpha 1$ is an essential receptor component for GDNF in the developing nervous system and kidney. Neuron 21:53-62.

Courtneidge SA, Fumagalli S, Koegl M, Superti-Furga G, Twamley-Stein GM (1993) The Src family of protein tyrosine kinases: regulation and functions. Dev Suppl 1993:57-64.

Crisanti-Combes P, Lorient AM, Girard A, Pessac B, Wasseff M, Calothy G (1982) Expression of neuronal markers in chick and quail embryo neuroretina cultures infected with Rous sarcoma virus. Cell Differ 11:45-54.

Datta SR, Brunet A, Greenberg ME (1999) Cellular survival: a play in three Akts. Genes Dev 13:2905-2927.

D'Mello SR, Galli C, Ciotti T, Calissano P (1993) Induction of apoptosis in cerebellar granule neurons by low potassium: inhibition of death by insulin-like growth factor I and cAMP. Proc Natl Acad Sci USA 90:10989-10993.

D'Mello SR, Borodezt K, Soltoff SP (1997) Insulin-like growth factor and potassium depolarization maintain neuronal survival by distinct pathways: possible involvement of PI-3 kinase in IGF-1 signaling. J Neurosci 17:1548-1560

Dudek H, Datta SR, Franke TF, Birnbaum MJ, Yao R, Cooper GM, Segal RA, Kaplan DR, Greenberg ME (1997) Regulation of neuronal survival by the serine-threonine protein kinase Akt. Science 275:661-665.

Ebendal T, Tomac A, Hoffer BJ, Olson L (1995) Glial cell line-derived neurotrophic factor stimulates fiber formation and survival in cultured neurons from peripheral autonomic ganglia. J Neurosci Res 40:276-284.

Enokido Y, de Sauvage F, Hongo J-A, Ninkina N, Rosenthal A, Buchman VL, Davies AM (1998) GFR $\alpha 4$ and the tyrosine kinase Ret form a functional receptor complex for persephin. Curr Biol 8:1019-1022.

Frisch SM, Francis H (1994) Disruption of epithelial cell-matrix interactions induces apoptosis. J Cell Biol 124:619-626.

Haltmeier H, Rohrer H (1990) Distinct and different effects of the oncogenes $v$-myc and $v$-src on avian sympathetic neurons: retroviral transfer of $v$-myc stimulates neuronal proliferation whereas $v$-src transfer enhances neuronal differentiation. J Cell Biol 110:2087-2098.

Hanke JH, Gardner JP, Dow RL, Changelian PS, Brissette WH, Weringer EJ, Pollock BA, Connelly PA (1996) Discovery of a novel, potent, and Src family-selective tyrosine kinase inhibitor. J Biol Chem 271:695-701.

Harder T, Simons K (1999) Clusters of glycolipid and glycosylphosphatidylinositol-anchored proteins in lymphoid cells: accumulation of actin regulated by local tyrosine phosphorylation. Eur J Neurosci 29:556-562.

Henderson CE, Phillips HS, Pollock RA, Davies AM, Lemeulle C, Armanini M, Simpson LC, Moffet B, Vandlen RA, Koliatsos VE, Rosenthal A (1994) GDNF: a potent survival factor for motoneurons present in peripheral nerve and muscle. Science 266:1062-1064.

Heuckeroth RO, Lampe PA, Johnson Jr EM, Milbrandt J (1998) Neurturin and GDNF promote proliferation and survival of enteric neuron and glial progenitors in vitro. Dev Biol 200:116-129.

Horger BA, Nishimura MC, Armanini MP, Wang LC, Poulsen KT, Rosenblad C, Kirik D, Moffat B, Simmons L, Johnson Jr EM, Milbrandt J, Rosenthal A, Bjorklund A, Vandlen RA, Hynes MA, Phillips HS (1998) Neurturin exerts potent actions on survival and function of midbrain dopaminergic neurons. J Neurosci 18:4929-4937.

Janes PW, Ley SC, Magee AI (1999) Aggregation of lipid rafts accompanies signaling via the $\mathrm{T}$ cell antigen receptor. J Cell Biol 147:447-461

Jing S, Wen DZ, Yu YB, Holst PL, LuoY, Fang M, Tamir R, Antonio L, Hu Z, Cupples R, Louis JC, Hu S, Altrock BW, Fox GM (1996) GDNF-induced activation of the Ret protein tyrosine kinase is mediated by GDNFR- $\alpha$, a novel receptor for GDNF. Cell 85:1113-1124.

Kotzbauer PT, Lampe PA, Heuckeroth RO, Golden JP, Creedon DJ, Johnson Jr EM, Milbrandt J (1996) Neurturin, a relative of glial cell line-derived neurotrophic factor. Nature 384:467-470.

Lin L-FH, Doherty DH, Lile JD, Bektesh S, Collins F (1993) GDNF: a glial cell line-derived neurotrophic factor for midbrain dopaminergic neurons. Science 260:1130-1132.

Lindahl M, Timmusk T, Rossi J, Saarma M, Airaksinen MS (2000) Expression and alternative splicing of mouse Gfr $\alpha 4$ suggest roles in endocrine cell development. Mol Cell Neurosci 15:522-533.

Lowell CA, Soriano P (1996) Knock-outs of Src family kinases: stiff bones, wimpy T cells, and bad memories. Genes Dev 10:1845-1857.

Martin DP, Schmidt RE, DiStefano PS, Lowry OH, Carter JG, Johnson Jr EM (1992) Biochemical characterization of programmed cell death in NGF-deprived sympathetic neurons. J Neurobiol 23:1205-1220.

McCubrey JA, Smith SR, Algate PA, Devente JE, White MK, Steelman LS (1993) Retroviral infection can abrogate the factor dependency of hematopoietic cells by autocrine and non-autocrine mechanisms depending on the presence of a functional viral oncogene. Oncogene 8:2905-2915.
Melillo RM, Barone MV, Lupoli G, Cirafici AM, Carlomagno F, Visconti R, Matoskova B, Di Fiore PP, Vecchio G, Fusco A, Santoro M (1999) Ret-mediated mitogenesis requires Src kinase activity. Cancer Res 59:1120-1126.

Milbrandt J, de Sauvage FJ, Fahrner TJ, Baloh RH, Leitner ML, Tansey MG, Lampe PA, Heuckeroth RO, Kotzbauer PT, Simburger KS, Golden JP, Davies JA, Vejsada R, Kato AC, Hynes M, Sherman D, Nishimura M, Wang LC, Vandlen R, Moffat B, Klein RD, Poulsen K, Gray C, Garces A, Henderson CE, Phillips HS, Johnson Jr EM (1998) Persephin, a novel neurotrophic factor related to GDNF and neurturin. Neuron 20:245-253.

Miller TM, Johnson Jr EM (1996) Metabolic and genetic analyses of apoptosis in potassium/serum-deprived rat cerebellar granule cells. J Neurosci 16:7487-7495.

Miller TM, Tansey MG, Johnson Jr EM, Creedon DJ (1997) Inhibition of phosphatidylinositol-3 kinase activity blocks depolarization- and insulin-like growth factor I-mediated survival of cerebellar granule cells. J Biol Chem 272:9847-9853.

Moulder KL, Onodera O, Burke JR, Strittmatter WJ, Johnson Jr EM (1999) Generation of neuronal intranuclear inclusions by polyglutamine-GFP: analysis of inclusion clearance and toxicity as a function of polyglutamine length. J Neurosci 19:705-715.

Muto M, Yoshimura M. Okayama M, Kaji A (1977) Cellular transformation and differentiation. Effect of Rous sarcoma virus on sulfated proteoglycan synthesis by chicken chondrocytes. Proc Natl Acad Sci USA 74:4173-4177.

Oppenheim RW, Houenou LJ, Johnson JE, Lin LFH, Li LX, Lo AC, Newsome AL, Prevette DM, Wang SW (1995) Developing motor neurons rescued from programmed and axotomy-induced cell death by GDNF. Nature 373:344-346.

Osterhout DJ, Wolven A, Wolf RM, Resh MD, Chao MV (1999) Morphological differentiation of oligodendrocytes requires activation of Fyn tyrosine kinase. J Cell Biol 145:1209-1218.

Philpott KL, McCarthy MJ, Klippel A, Rubin LL (1997) Activated phosphatidylinositol-3 kinase and Akt kinase promote survival of superior cervical neurons. J Cell Biol 139:809-815.

Schlessinger J (2000) New roles for Src kinases in control of cell survival and angiogenesis. Cell 100:293-296.

Sheets ED, Holowka D, Baird B (1999) Critical role for cholesterol in Lyn-mediated tyrosine phosphorylation of FceRI and their association with detergent-resistant membranes. J Cell Biol 145:877-887.

Simons K, Ikonen E (1997) Functional rafts in cell membranes. Nature 387:569-572.

Soler RM, Dolcet X, Encinas M, Egea J, Bayascas JR, Comella JX (1999) Receptors of the glial cell line-derived neurotrophic factor family of neurotrophic factors signal cell survival through the phosphatidylinositol-3 kinase pathway in spinal cord motoneurons. J Neurosci 19:9160-9169.

Tansey MG, Baloh RH, Milbrandt J, Johnson Jr EM (2000) GFR $\alpha$ mediated localization of RET to lipid rafts is required for effective downstream signaling, differentiation, and neuronal survival. Neuron 25:611-623.

Thomas SM, Brugge JS (1997) Cellular functions regulated by Src family kinases. Annu Rev Cell Dev Biol 13:513-609.

Thomas SM, Hayes M, D'Arcangelo G, Armstrong RC, Meyer BE (1991) Induction of neurite outgrowth by $v$-src mimics critical aspects of nerve growth factor-induced differentiation. Mol Cell Biol 11:4739-4750.

Treanor JJS, Goodman L, de Sauvage F, Stone DM, Poulsen KT, Beck CD, Gray C, Armanini MP, Pollock RA, Hefti F, Phillips HS, Goddard A, Moore MW, Buj-Bello A, Davies AM, Asai N, Takahashi M, Vandlen R, Henderson CE, Rosenthal A (1996) Characterization of a multicomponent receptor for GDNF. Nature 382:80-83.

Trupp M, Ryden M, Jornvall H, Funakoshi H, Timmusk T, Arenas E, Ibañez CF (1995) Peripheral expression and biological activities of GDNF, a new neurotrophic factor for avian and mammalian peripheral neurons. J Cell Biol 130:137-148.

Tsui-Pierchala BA, Putcha GV, Johnson Jr EM 2000 Phosphatidylinositol-3 kinase is required for the trophic, but not the survivalpromoting, actions of NGF on sympathetic neurons. J Neurosci 20:7228-7237.

Virdee K, Xue L, Hemmings BA, Goemans C, Heumann R, Tolkovsky AM (1999) Nerve growth factor-induced PKB/Akt activity is sustained by phosphoinositide-3 kinase-dependent and independent signals in sympathetic neurons. Brain Res 837:127-142.

Wong BR, Besser D, Kim N, Arron JR, Vologodskaia M, Hanafusa H, Choi Y (1999) TRANCE, a TNF family member, activates Akt/PKB through a signaling complex involving TRAF6 and c-Src. Mol Cell 4:1041-1049

Xia Z, Dudek H, Miranti CK, Greenberg ME (1996) Calcium influx via the NMDA receptor induces immediate early gene transcription by a MAP kinase/ERK-dependent mechanism. J Neurosci 16:5425-5436.

Yoshimura M, Iwasaki Y, Kaji A (1981) In vitro differentiation of chicken embryo skin cells transformed by Rous sarcoma virus. J Cell Physiol 109:373-385. 